Pak. j. sci. ind. res. Ser. B: biol. sci. 201154 (3) 126-130

\title{
Effect of Growth Regulators for in-vitro Mass Multiplication of Marigold
}

\author{
Beena Naqvi* and Yasmeen Tariq \\ Plant Tissue Culture Lab., PCSIR Laboratories Complex, Shahrah-e-Dr. Salimuzzaman Siddiqui, \\ Karachi-75280, Pakistan
}

(received May 11, 2010; revised October 27, 2010; accepted December 22, 2010)

\begin{abstract}
This study describes an effective and reproducible protocol for the mass multiplication of marigold (Tagetes erecta L.) for commercial purpose. Twenty five different combinations of BAP, IAA, $\mathrm{GA}_{3}$ and $\mathrm{AgNO}_{3}$ were added to the basal MS medium to culture marigold explants. The highest mean number $(4.83 \pm 0.49)$ and length $(5.28 \mathrm{~cm} \pm 1.06)$ of healthy shoots per explant was observed in media supplemented with $2 \mathrm{mg} / \mathrm{L}$ BAP along with $2 \mathrm{mg} / \mathrm{L}$ IAA. When these shoots were sub-cultured for root development, the maximum number $(17.08 \pm 2.44)$ and length $(13.67 \mathrm{~cm} \pm 0.98)$ of roots were produced in media supplemented with $4 \mathrm{mg} / \mathrm{L}$ BAP and $2 \mathrm{mg} / \mathrm{L}$ IAA. Addition of gibberellic acid and $\mathrm{AgNO}_{3}$ did not have any significant effect on shoot proliferation and root development of marigold.
\end{abstract}

Keywords: tissue culture, marigold, shoot proliferation, root proliferation, Tagetes erecta L.

\section{Introduction}

Tagetes erecta L. (marigold) is a member of the family Asteraceae. This family includes some thirty species of strongly scented annual or perennial herbs that are distributed throughout the world. Marigold is an important ornamental crop having a high market value not only for its flowers but also for its industrial value. This crop is a source of highly desirable components like pigments, lutein, essential oils, thiophene, etc. It possesses nematicidal, fungicidal and insecticidal activities and is also used in poultry feed (Qingxiang et al., 2008;Godoy-Hernandez et al., 2006; Karadas et al., 2006; Pudasaini et al., 2006; Barzana et al., 2002; Vanegas et al., 2002).

The development of an effective protocol for in-vitro propagation and mass multiplication using tissue culture technique is highly desirable for elite or exotic varieties of marigold (Choi and Chung, 2007; MirandaHam et al., 2006; Hayashi et al., 2005; Vanegas et al., 2002; Delgado-Vargas et al., 2000). Gibberellic acid was used for tissue culture of immature unpollinated disc florets (Kothari and Chandra, 1984). Benzyl adenine, Gibberellic acid and Indole acetic acid were used for leaf-callus and suspension cultures (Kothari and Chandra, 1986). Benzyl adenine and Indole acetic acid were found effective for regeneration from

*Author for correspondence; E-mail: nbeena25@hotmail.com hypocotyls and shoot-tip proliferation from adult plants (Godoy-Harnandez et al., 2006; Misra and Datta 1999). Regeneration through leaf segments using l-glutamine, l-arginine, adenine sulphate and 6-benzyladenine was also observed (Ault, 2002; Venegas et al., 2002; Misra and Datta, 2001). Reports on the genetic transformation of marigold with Agrobacterium rhizogenes (Giri and Narasu, 2000) and A. tumefaciens (Godoy-Hernandez et al., 2006) are also available. The present study was designed to optimize protocol for in-vitro mass multiplication and healthy rooting of marigold.

\section{Materials and Methods}

Marigold (Tagetes erecta) seeds were surface sterilized in a solution of $50 \%$ sodium hypochlorite with a few drops of Tween 20 for 40 min followed by three rinses with autoclaved double distilled deionized water. The disinfected seeds were germinated on Murashige and Skoog (1962) basal medium (MS) supplemented with $30 \mathrm{~g} / \mathrm{L}$ sucrose and $10 \mathrm{~g} / \mathrm{L}$ agar at $\mathrm{pH}$ 5.74. Fifteen seeds were placed in each glass jar for germination $(10.5 \mathrm{~cm} \times 5 \mathrm{~cm})$, with $20 \mathrm{~mL}$ of medium and incubated at $25 \pm 2{ }^{\circ} \mathrm{C}$ under $16 \mathrm{~h}$ light $(40-50 \mu \mathrm{mol})$ in the growth room. Germinated seedlings were transferred to fresh medium with the same composition and were allowed to grow for two weeks. After two weeks, explants of $2 \mathrm{~mm}$ size were excised from these seedlings and placed on MS medium supplemented with different 
combinations of 6-benzylaminopurine 2, 3, $4 \mathrm{mg} / \mathrm{L}$ (BAP), indole-3-acetic acid 1, 2 mg/L (IAA), Gibberellic acid $0.5 \mathrm{mg} / \mathrm{L}\left(\mathrm{GA}_{3}\right)$ and silver nitrate $\left(\mathrm{AgNO}_{3}\right) 3 \mathrm{mg} / \mathrm{L}$ (Table 1). All jars were labelled and kept in controlled environment at $25 \pm 2{ }^{\circ} \mathrm{C}$ under $16 \mathrm{~h}$ light $(40-50 \mu \mathrm{mol})$ in the growth room.

Ten explants were used for each treatment. The experiments were repeated independently at least three times with reproducible results. The data on average number and length of shoot and root were collected and analyzed.

Table 1. MS medium supplemented with various combinations of 6-benzylaminopurine (BAP), indole3-acetic acid (IAA), gibberellic acid $\left(\mathrm{GA}_{3}\right)$ and silver nitrate $\left(\mathrm{AgNO}_{3}\right)$

\begin{tabular}{lllll}
\hline \hline & \multicolumn{4}{c}{ Treatment $\mathrm{mg} / \mathrm{g}$} \\
\cline { 2 - 5 } Media Code & BAP & IAA & $\mathrm{GA}_{3}$ & $\mathrm{AgNO}_{3}$ \\
\hline G1 & 0 & 0 & 0 & 0 \\
G2 & 2 & 0 & 0.5 & 0 \\
G3 & 2 & 0 & 0 & 3 \\
G4 & 2 & 1 & 0 & 0 \\
G5 & 2 & 1 & 0.5 & 0 \\
G6 & 2 & 1 & 0 & 3 \\
G7 & 2 & 2 & 0 & 0 \\
G8 & 2 & 2 & 0.5 & 0 \\
G9 & 2 & 2 & 0 & 3 \\
G10 & 3 & 0 & 0.5 & 0 \\
G11 & 3 & 0 & 0 & 3 \\
G12 & 3 & 1 & 0 & 0 \\
G13 & 3 & 1 & 0.5 & 0 \\
G14 & 3 & 1 & 0 & 3 \\
G15 & 3 & 2 & 0 & 0 \\
G16 & 3 & 2 & 0.5 & 0 \\
G17 & 3 & 2 & 0 & 3 \\
G18 & 4 & 0 & 0.5 & 0 \\
G19 & 4 & 0 & 0 & 3 \\
G20 & 4 & 1 & 0 & 0 \\
G21 & 4 & 1 & 0.5 & 0 \\
G22 & 4 & 1 & 0 & 3 \\
G23 & 4 & 2 & 0 & 0 \\
G24 & 4 & 2 & 0.5 & 0 \\
G25 & 4 & 2 & 0 & 3 \\
\hline \hline & & & & \\
\hline
\end{tabular}

\section{Results and Discussion}

A consistent and reproducible protocol is presented for the regeneration and mass multiplication of marigold through tissue culture technique. Out of the tested twenty five different Murashige and Skoog (1962) basal media containing 6-benzylaminopurine (BAP 2, 3, 4 mg/L), indole acetic acid (IAA 1, $2 \mathrm{mg} / \mathrm{L}$ ), gibberellic acid ( $\mathrm{GA}_{3}$ $0.5 \mathrm{mg} / \mathrm{L}$ ) and silver nitrate $\left(\mathrm{AgNO}_{3} 3 \mathrm{mg} / \mathrm{L}\right)$, only four combinations were found to be effective for in-vitro mass multiplication of shoots (Table 2).

It was noted that media supplemented with BAP $2 \mathrm{mg} / \mathrm{L}$ and IAA $2 \mathrm{mg} / \mathrm{L}$ gave the best results. This medium not only supported the highest mean number $(4.83 \pm 0.49)$, but also allowed vigorous growth of shoots (Fig. 1).

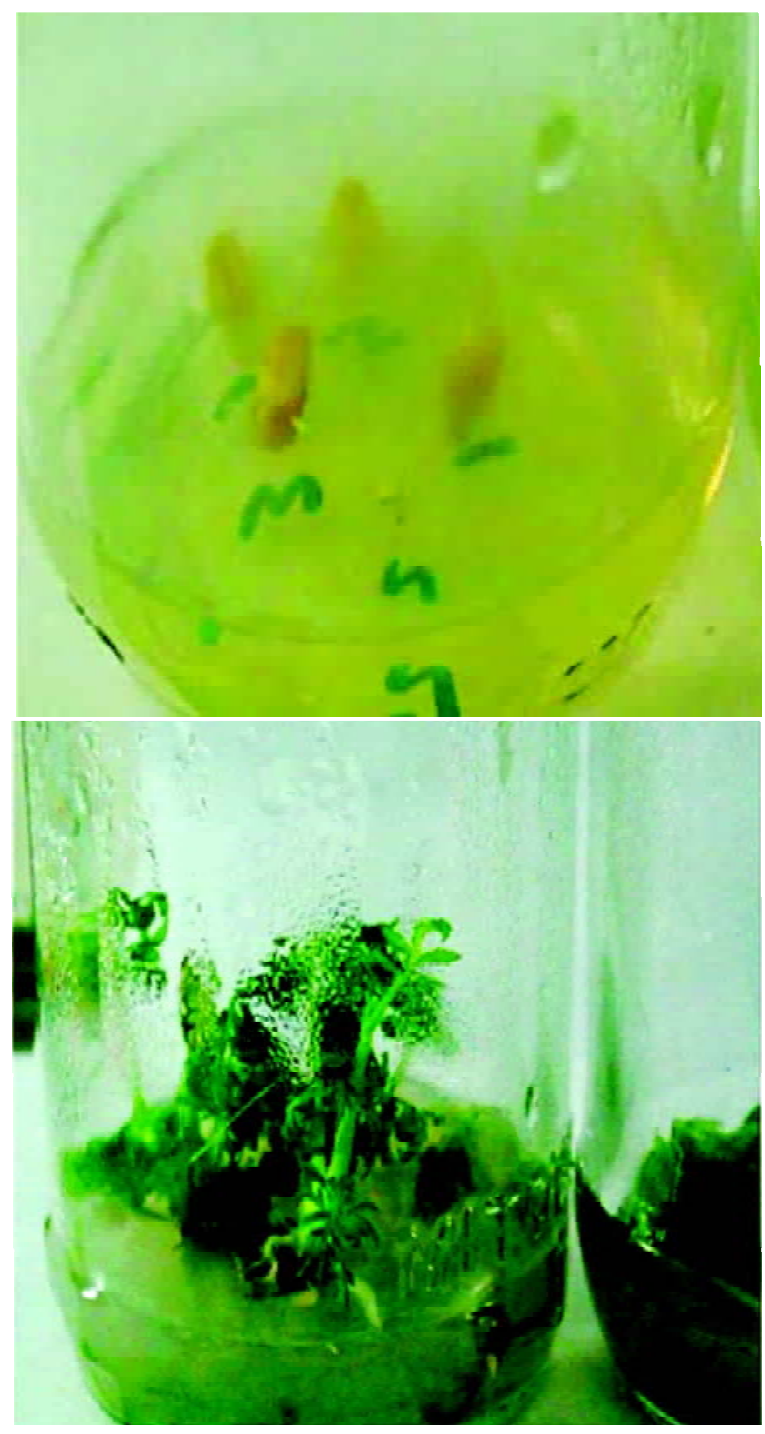

Fig 1. Different stages of in vitro shoot proliferation of marigold. 
Table 2. Effective media for in-vitro production of shoots and their length

\begin{tabular}{llll}
\hline \hline $\begin{array}{l}\text { Media Growth } \\
\text { regulators code }\end{array}$ & $\begin{array}{l}\text { Shoot/explants } \\
(\text { Mean } \pm \text { SE) }\end{array}$ & $\begin{array}{l}\text { Shoot length }(\mathrm{cm}) \\
(\text { Mean } \pm \text { SE) }\end{array}$ \\
\hline G7 $\quad(2,2,0,0)$ & $4.83 \pm 0.49$ & $5.28 \pm 1.06$ \\
G13 $\quad(3,1,0.5,0)$ & $4.50 \pm 0.71$ & $3.34 \pm 0.53$ \\
G25 $\quad(4,2,0,3)$ & $4.33 \pm 0.64$ & $3.96 \pm 0.72$ \\
G4 $\quad(2,1,0,0)$ & $4.00 \pm 0.71$ & $4.54 \pm 1.11$ \\
\hline \hline
\end{tabular}

The shoots grown on this medium were healthy and longer in size $(5.28 \pm 1.06 \mathrm{~cm})$ as compared to the other media tested (Fig. 2). Other effective concentration of growth regulators for shoot proliferation was BAP $2 \mathrm{mg} / \mathrm{L}$ and IAA 1mg/L but the shoots produced were weak and smaller in size. Although media supplemented with BAP (3 mg/L), IAA (1 mg/L), GA 3 (0.5 mg/L), BAP (4 mg/L), IAA (2 mg/L) and $\mathrm{AgNO}_{3}(3 \mathrm{mg} / \mathrm{L})$ also produced good number of shoots per explant but the shoots were smaller with slower growth (Fig.2).

Previous studies on optimization of in-vitro propagation of marigold showed that effective concentration of BAP was $0.1 \mathrm{mg} / \mathrm{L}$ to $5.0 \mathrm{mg} / \mathrm{L}$, IAA was 0.2 to $3.0 \mathrm{mg} / \mathrm{L}$ and $\mathrm{GA}_{3}$ was 0.5 to $20 \mathrm{mg} / \mathrm{L}$ (Godoy-Hernandez et al., 2006; Vanegas et al., 2002; Chakrabarty et al. 2000; Misra and Datta, 1999. The present results showed that $2 \mathrm{mg} / \mathrm{L}$ concentration of both the BAP and the IAA was enough for producing good number and length of shoots.

The media effective for shoot proliferation did not help in formation of healthy roots for the establishment of plants in soil (Misra and Datta, 1999). When tissue culture-derived shoots were sub-cultured on twenty five different media (Fig.3), only two were found to be effective for in-vitro rooting. Sub-cultured shoots on media supplemented with BAP (4 mg/L) and IAA ( $2 \mathrm{mg} / \mathrm{L}$ ) produced the most extensive root system and the highest mean number and size of roots were observed (Table 3).

Table 3: Effective media for in-vitro production of roots and their length (in $\mathrm{cm}$ )

\begin{tabular}{lll}
\hline \hline $\begin{array}{l}\text { Media Growth } \\
\text { regulators code }\end{array}$ & $\begin{array}{l}\text { Roots/explant } \\
(\text { Mean } \pm \text { SE) }\end{array}$ & $\begin{array}{l}\text { Root length }(\mathrm{cm}) \\
(\text { Mean } \pm \text { SE) }\end{array}$ \\
\hline G23 (4, 2, 0, 0) & $17.08 \pm 2.44$ & $13.67 \pm 0.98$ \\
G12 $\quad(3,1,0,0)$ & $16.50 \pm 1.23$ & $5.42 \pm 1.49$ \\
\hline \hline
\end{tabular}

Misra and Datta (1999) reported 100\% rooting on 0.05 mg/L NAA within 7 days of incubation; they also observed $100 \%$ rooting in media supplemented with IAA and IBA but associated with some callusing and vitrification of shoots. Other medium effective for root formation was BAP (3 mg/L) and IAA (1 mg/L) but growth of roots was stunted and their size was short (Fig. 3). However, addition of gibberellic acid $\left(\mathrm{GA}_{3}\right)$ and $\mathrm{AgNO}_{3}$ in media was not found effective for root formation in marigold. The results suggested that root initiation requires BAP (4 mg/L), IAA (2 mg/L) and the same media was good for healthy growth of roots (Fig. 4).

Present study also reveals that addition of $\mathrm{GA}_{3}$ and $\mathrm{AgNO}_{3}$ did not have any significant effect on direct shoot or root proliferation from explant (Fig. 2). In contrast, Godoy-Hernandez et al. (2006) found a

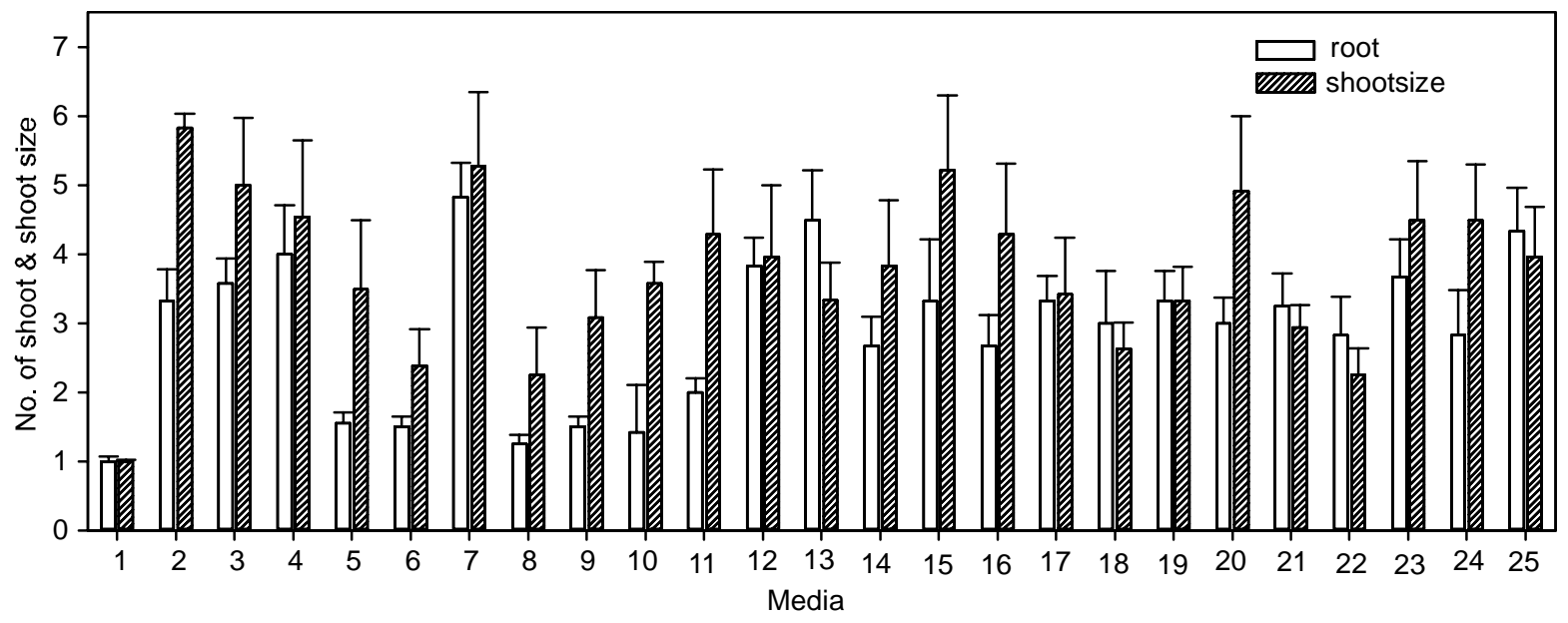

Fig. 2. Effects of BAP, IAA, $\mathrm{GA}_{3}$ and $\mathrm{AgNO}_{3}$ on shoot regeneration of marigold. 


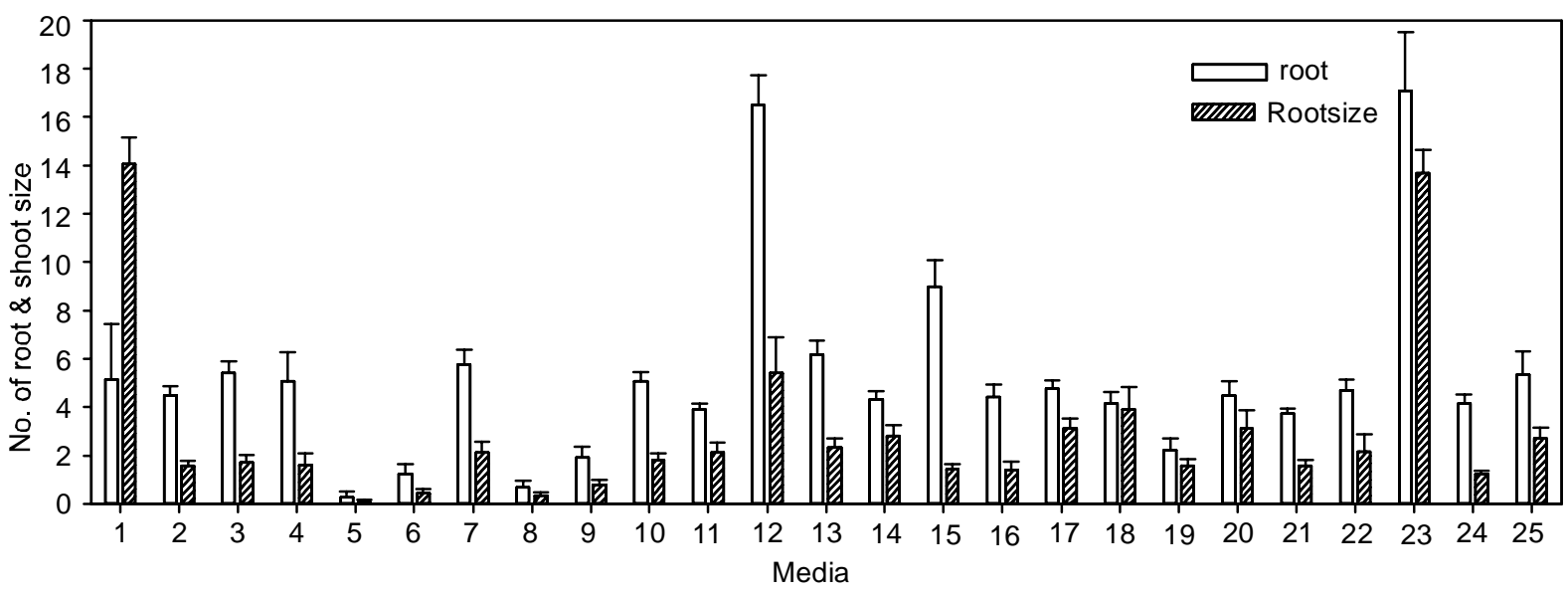

Fig. 3. Effects of BAP, IAA, $\mathrm{GA}_{3}$ and $\mathrm{AgNO}_{3}$ on root formation of marigold.

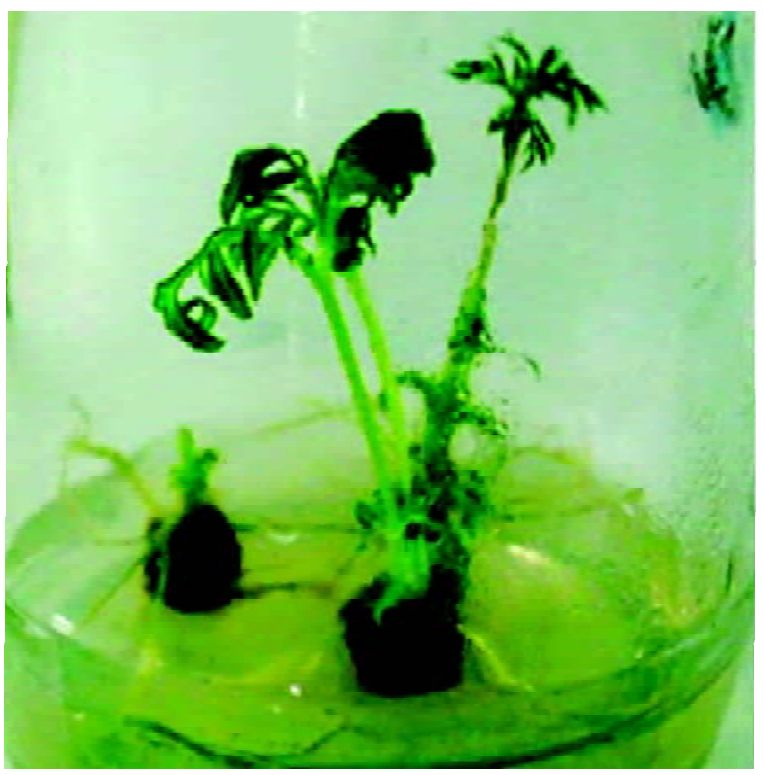

Fig. 4. In-vitro root proliferation of marigold.

significant role of gibberellic acid for the induction of shoot proliferation of marigold. $\mathrm{AgNO}_{3}$ along with BAP has been used successfully for shoot proliferation of marigold by Misra and Datta (2001) and Fuentes et al. (2000) but in the present study, results were not successful.

This study was conducted to select the most effective concentration and combination of growth regulators for mass multiplication and for healthy rooting, through tissue culture and it was found that use of BAP and IAA in the concentrations mentioned above were enough for both shoot and root formation of marigold. Addition of other growth regulators and changing the concen- tration either reduced the number of shoots per explant or reduced the size of shoots.

\section{References}

Ault, J.R. 2002. Micropropagation of the rare lakeside daisy (Hymenoxys acaulis var. glabra). Horticultural Sciences, 37: 200-201.

Barzana, E., Rubio, D., Santamaria, R.I., Garcia-Correa, O., Garcia, F., Ridaura Sanz, V.E., Lopez-Mungia, A. 2002. Enzyme mediated solvent extraction of carotenoids from marigold flowers (Tagetes erecta). Journal of Agricultural and Food Chemistry, 50: 4491-4496.

Chakrabarty, D., Mandal, A.K.A., Datta, S.K. 2000. Retrieval of new colored chrysanthemum through organogenesis from sectorial chimera. Current Science, 78: 1060-1061.

Choi, J.M., Chung, H.T. 2007. Influence of pre-plant micronutrient mixes and ammonium to nitrate ratios in fertilizer solution on growth and micronutrient contents of marigold in plug culture. Journal of Plant Nutrition, 30: 915-926.

Delgado-Vargas, F., Jimenez, A.R., Paredes-Lopez, O. 2000. Natural pigments: Carotenoids, anthocyanins, and betalains-characteristics, biosynthesis, processing and stability. Critical Reviews in Food Science and Nutrition, 40: 173-289.

Fuentes, S.R.L., Calleiros, M.B.P., Manetti-Filho, J., Vieira, G.E. 2000. The effects of silver nitrate and different carbohydrate sources on somatic embryogenesis in Coffea canephora. Plant Cell Tissue and Organ Culture, 60: 5-13.

Giri, A., Narasu, M.L. 2000. Transgenic hairy roots: recent trends and applications. Biotechnology 
Advances, 18: 1-22.

Godoy-Hernandez, G., Aviles-Berzunza, E.A., Concha, L.C., Miranda-Ham, M.L. 2006. Agrobacteriummediated transient transformation of marigold (Tagetes erecta). Plant Cell Tissue and Organ Culture, 84: 365-368.

Hayashi, T., Oka, H., Ito, Y., Goto, T., Ozeki, N., Itakura, Y., Matsumoto, H., Ohno, H., Yoshida, K., Miyazawa, T., Nagas, H. 2005. An HPLC method for the analysis of marigold color in food using lutein as an indicator. Journal of Liquid Chromatography and Related Technologies, 27: 335-349.

Karadas, F., Grammenidis, E., Surai, P.F., Acamovic, T., Sparks, N.H.C. 2006. Effect of carotenoids from lucerne, marigold and tomato on egg yolk pigmentation and carotenoid composition. British Poultry Science, 47: 561-566.

Kothari, S.L., Chandra, N. 1986. Plant regeneration from callus and suspension cultures of Tagetes erecta L. (African marigold) Journal of Plant Physiology, 122: 235-241.

Kothari, S.L., Chandra N. 1984. Plant regeneration from cultured disc florets of Tagetes erecta L. Journal of Plant Physiology, 117: 105-108.

Kumar, A., Singh, S.K., Sharma, S.K., Ragava, S.P.S., Misra, R. 2004. Journal of Horticultural Science and Biotechnology,79: 260-266.

Miranda-Ham, M.L., Castro-Concha, L.A., Aviles-
Berzunza, E., Godoy-Hernandez, G. 2006. Plant regeneration from shoot apex-derived culluses of marigold (Tagetes erecta L.). Horticultural Sciences, 41: 1518-1520.

Misra, P., Datta, S.K. 2001. Direct differentiation of shoot buds in leaf segments of white marigold (Tagetes erecta L.). In vitro Cellular and Developmental Biology Plant, 37: 466-470.

Misra, P., Datta, S.K. 1999. In vitro propagation of white marigold (Tagetes erecta L.) through shoot tip proliferation. Current Science, 77: 101-103.

Murashige, T., Skoog, F. 1962. A revised medium for rapid growth and bioassays with tobacco tissue cultures. Plant Physiology, 15: 472-497.

Pudasaini, M.P., Nicole, V., Maurice, M. 2006. Effect of marigold (Tagetes patula) on population dynamics of Pratylenchus penetrans in a field. Nematology, 8: 477-484.

Qingxiang, M., Xiang, X., Yanxiang, G., Qi, W., Jian, Z. 2008. Optimisation of supercritical carbon dioxide extraction of lutein esters from marigold (Tagetes erecta L.) with soybean oil as a co-solvent. International Journal of Food Science and Technology, 43: 1763-1769.

Vanegas, P.E., Cruz-Hernandes, A., Valverde, M.E., Paredes-Lopez, O. 2002. Plant regeneration via organogenesis in marigold. Plant Cell Tissue and Organ Culture, 69: 279-283 